\title{
Domestic Capital Flow vs Foreign Capital InFlow in Nigeria: Which One Matter Most?
}

\author{
Udi JOSHUA ${ }^{1}$ \\ Adewale BEKE ${ }^{2}$ \\ Peter Chika UZOMBA ${ }^{3}$
}

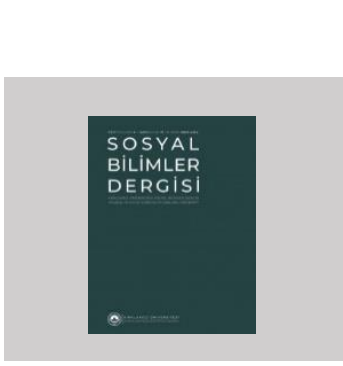

\begin{abstract}
The path to achieving economic growth as well as the ultimate economic development is the greatest macroeconomic goal sought after by all global economies. Traditionally, these resources are classified as labour and capital. Therefore, we focus on the capital factor and its impact on economic growth. This study for the first time in Nigeria classifies the capital resources into two categories namely domestic and foreign capital and to compare their respective influence on economic growth. The results show that domestic capital is more influential in promoting the cause of economic growth whereas external debt as one of the components of foreign capital exerts serious level of threat to the course of economic expansion in Nigeria. Thus, this study recommends the need for the authority concern to look inward in resolving it economic challenges through domestic mobilization of resources. Sourcing for external capital should strictly take the form of FDI and foreign aids to augment the domestic capital for economic reasons with the view to expand the productive capacity of the economy.

Key Words: Economic growth, external capital, domestic capital, time-series data, ARDL approach.
\end{abstract} Article Type Research Article

Application Date 2021-03-26

Acceptance Date 2021-06-05

$\mathrm{DOI}$

10.47140/kusbder.903571

${ }^{1}$ Corresponding Author: Federal University Lokoja Department of Economics. P.M.B. 1154 Lokoja, Kogi State, Nigeria, E-mail: udijoshua@yahoo.com, https://orcid.org/0000-0002-7862-0547

${ }^{2}$ Federal University Lokoja Department of Economics. P.M.B. 1154 Lokoja, Kogi State, Nigeria, E-mail: adewalebeke@yahoo.com

${ }^{3}$ Federal University Lokoja Department of Economics. P.M.B. 1154 Lokoja, Kogi State, Nigeria, E-mail: uzombapc@gmail.com 


\title{
Nijerya'da Yurtiçi Sermaye Akışına Karşı Yabancı Sermaye Akışı: Hangisi En Önemli?
}

\author{
Udi JOSHUA ${ }^{4}$ \\ Adewale BEKE ${ }^{5}$ \\ Peter Chika UZOMBA ${ }^{6}$
}

Öz

\begin{tabular}{c} 
SOSYAL \\
BiLiMLER \\
DERGISI \\
\hline Makale Türü \\
Araştırma Makalesi \\
Başvuru Tarihi \\
26.03.2021 \\
Kabul Tarihi \\
05.06.2021 \\
DOI \\
\hline 10.47140/kusbder.903571
\end{tabular}

Ekonomik büyümeye ve nihai ekonomik kalkınmaya ulaşmanın yolu, tüm küresel ekonomiler tarafından aranan en büyük makroekonomik hedeftir. Geleneksel olarak, bu kaynaklar emek ve sermaye olarak sınıflandırılır. Bu nedenle okuyacağınız çalışmada sermaye faktörüne ve bunun ekonomik büyüme üzerindeki etkisine odaklanıyoruz. Nijerya'da ilk kez yapılan bu çalışma, kaynak sermayeyi yerli ve yabancı sermaye olmak üzere iki kategoriye ayırmakta ve bunların ekonomik büyüme üzerindeki etkilerini karşılaştırmaktadır. Sonuçlar, yerli sermayenin ekonomik büyümenin nedenini desteklemede daha etkili olduğunu, oysa dış borcun Nijerya'daki ekonomik genişlemenin gidişatına ciddi düzeyde tehdit olduğunu göstermektedir. Bu nedenle, bu çalışma, otorite endişesinin, kaynakların ülke içinde seferber edilmesi yoluyla ekonomik zorlukları çözmede içe bakma ihtiyacını önermektedir. Ekonominin üretken kapasitesini genişletmek amacıyla dış sermayeye kaynak sağlanması kesinlikle doğrudan yabancı yatırım ve yerli sermayeyi ekonomik nedenlerle artırmak için yabancı yardımlar şeklinde olmalıdır.

Anahtar sözcükler: Ekonomik büyüme, dış sermaye, yerli sermaye, zaman serisi verileri, ARDL yaklaşımı.

\footnotetext{
${ }^{4}$ Sorumlu Yazar: Federal University Lokoja Department of Economics. P.M.B. 1154 Lokoja, Kogi State, Nigeria, E-mail: udijoshua@yahoo.com, https://orcid.org/0000-0002-7862-0547

${ }^{5}$ Federal University Lokoja Department of Economics. P.M.B. 1154 Lokoja, Kogi State, Nigeria, E-mail: adewalebeke@yahoo.com

${ }^{6}$ Federal University Lokoja Department of Economics. P.M.B. 1154 Lokoja, Kogi State, Nigeria, E-mail: uzombapc@gmail.com
} 


\section{Introduction}

The traditional growth model asserts that capital and labour as the main key factors that drive economic growth. This suggests that capital - both foreign and domestic forms are expected to drive the course of economic growth. Accordingly, foreign capital inflows such as foreign direct investment are expected to argument domestic savings and to induce domestic investment thereby influencing income positively. The two pioneering studies authored by Millikan and Rostow (1957) and Rosentein-Rodan (1961) submit that the main function of foreign resources to the domestic economy is to improve the rate of local capital formation which is expected to cater for both present and future investment needs in the economy. This foreign capital inflow will generate additional output to add up with the GDP, thereby increasing the gross national product of the recipient country.

Chenery and Stout (1967) submit that foreign aids promote self-sustenance by adding to the rate of domestic saving. Thus, it is arguable to say that if the elasticity of supply in the LDCs is not zero, there will be a positive linkage between domestic savings and foreign capital inflow. However, there is a mixed opinion from empirical pieces of evidence regarding the presumed complementarity role of external capital. While some studies advocate for the need to look inward in resolving economic distress in the home country, others support the need to involve external resources. For instance, Joshua (2019) adopted the ARDL approach for Nigeria between 1981 and 2017. The finding shows that FDI inflow is a promoter of economic growth. In contrast, Khobai et al. (2017) opposed the reality of the dynamics of FDI inflow in South Africa as supported by Zandile and Phiri (2019) for Burkina Faso. Zandile and Phiri (2019) failed to subscribe to the positive impact of FDI inflow. In recent time; particularly from 2015 due to the fall in the global oil price, Nigeria has been plunged into a serious recession which still lingers till date. This get worsen in the after math of the second fall in the global oil price in 2019 shortly before the COVID-19 pandemic. This is because the oil sector is the major source of revenue for the economy.

Given this, the government is expected to depend on foreign capital in the form of FDI, foreign aids to close up the domestic saving-investment gap in an attempt to stimulate economic growth. Today, the Nigerian government keeps contracting new external loans in a way that seems reckless without any perceived positive outcome. The rate of economic growth within the same period seems not to commensurate with the rate of foreign capital that flows into the country. For instance, the country has been the largest recipient of FDI inflow to African over a long period except for the fall between 2015 and 2018 (UNCTAD 2018). The statistical fact shows that in 2011 FDI inflow stood at $2.1 \%$ which dropped to $1.5 \%$ in 2012 and keep fluctuation to date. In the case of external 
borrowing, the rate increased from $1.8 \%$ to $2.9 \%$ between 2012 and 2015 , escalating to $4.7 \%$ in 2018. Foreign aids, on the other hand, experienced a persistent increase from 1.9\% to $2.4 \%$ and 3.3\% between 2012 to 2015 and 2018 respectively. Domestic savings, on the other hand, demonstrate a snare-like rate of growth. For instance, a domestic saving increased from $18.1 \%$ in 2012 to $15.8 \%$ in 2015, and then to $19.2 \%$ in 2017. However, the rate of GDP increased in a snare-like movement comparatively. In 2012, GDP stood at 3.9\% with a slight increase between 2015 and 2018 as $4.6 \%$ and $4.6 \%$. This raises serious concern for empirical investigation. Thus, this study empirically examines the impact of external capital on economic growth relative to domestic capital. The model incorporates the component of capital (both domestic and foreign capital) as independent variables against the GDP. The domestic saving as a proxy for domestic capital, while the foreign capital components include FDI inflow, external borrowing, and foreign aids. This study compares the respective impact of external capital and domestic capital to ascertain which one among the two exert more impact on economic growth in the face of economic crises orchestrated by fall in oil price couples with the significant fall in the aggregate demand. The rest of the study consists of a literature review, theoretical framework, results and discussion, and conclusion and policy direction.

\section{Empirical Literature Review}

It is presumed that capital inflow such as FDI, external debt are incurred to augment its domestic counterpart to meet the home investment demand. This according to the modernization theory and other relevant empirical evidence will improve the level of output as well as economic growth in the recipient economies. Asongu and Odhiambo (2020) examine the influence of FDI inflow in sub-Saharan Africa and found a positive correlation with economic expansion. Joshua et al. (2020) investigated the relationship between FDI inflow and economic advancement in South Africa through causality test. The findings from the estimation proved that FDI is a key driver of economic growth as subscribed by (Shahbaz et al. 2019 \& Joshua (2019). Gungor and Rigim (2017) investigate the FDI-induced nexus in Nigeria by adopting the ADRL approach. The outcome shows that FDI inflow is a driver of economic growth. Again, Joshua (2019) investigates the relationship between the variables under investigation in Nigeria.

The outcome indicates the positive influence of FDI in the quest to achieving economic growth. (Shahbaz et al., 2019 \& Balcilar et al., 2019) carry out similar study and found the spillover effect of FDI inflow in promoting economic growth. Shahbaz and Rahman (2012) investigate the case of Pakistan through ARDL bound test approach. The finding validates long-range co-movement between the series. The result further shows positive influence of FDI in promoting the course of economic growth. 
Gungor and Katircioglu (2010) validated the FDI-led nexus for Turkey as subscribed by the work of Gungor and Rigim (2017) for Nigeria. Similar studies that lent their support to the FDI-led growth nexus include Tshepo (2014), Abbes et al. (2015), and Nistor (2014). Borensztein et al. (1998) also lent support to the dynamic nature of FDI inflow in the host country. According to the study, the spillover effect of FDI inflow is potent enough to influence the course of economic advancement.

Studies (See Shahbaz et al. 2019; Almfraji \& Almsafir 2014) and (Omri and Kahoulib 2013; Shahbaz and Rahman 2012; Berthélemy \& Demurger 2000) obtain similar position concerning the positive influence of FDI. According to (Nair-Reichert and Weinhold 2001), the dynamics of FDI inflow is more noticed in a free economy relative to a closed economy. Tang et al. (2008) investigated the dynamic of FDI inflow and economic transformation in China and discovered a one-way link running from FDI inflow to home investment and economic growth.

Ayanwale (2007) and Joshua (2019) revealed that the impact of FDI inflow is positive, but insignificant for the economy of Nigeria. In the case of China, the impact of FDI inflow is noticed in the service sector in a transitory form (Chakraborty and Nunnenkamp 2008). According to Azman-Saini et al. (2010) achieving a minimum financial threshold is a necessary condition to harnessing the full potential effect of FDI inflow. Wang (2009) investigates the subject matter through the link between the manufacturing sector and the FDI inflow.

The results found that FDI inflow promotes economic growth through its spillover effect on the manufacturing sector for the 12 Asian economies aligning with the work of Yao (2006) for China. Omri et al. (2014) examine three regions and discovered a bidirectional link between FDI inflow and economic growth in the respective regions. However, the outcome further proves that the impact of FDI inflow is not in view without achieving a minimum threshold of financial improvement in the domestic economy validating the work of (Hermes and Lensink, 2003).

Fedderke and Romm (2006) investigate the FDI-led hypothesis for South Africa and the outcome validates the complementarity role of FDI inflow. Asongu and Kodila-Tedila (2013) investigate the empirical link between trade, foreign aids, and terror. The findings revealed that bilateral aids are a necessary but not sufficient condition to solve the problem of terrorism on trade which by extend economic growth. The implication is that a threat to trade will transcend to stagnating economic growth in the long-run. Prasanna (2010) investigates the link between FDI inflow and economic growth in India. The outcome revealed that the direct impact of FDI inflow on home investment is positively 
significant. In contrast, other extant empirical literatures contend with the view of the modernization theory.

Theoretically, the dependency theory asserts that FDI inflow is an agent that foster economic retardation. For instance, studies with opposing views include (Abdouli and Hammami 2017). The study investigate the link between the series and found that FDI inflow exerts a negative impact on economic growth in Egypt and Lebanon. The study of Adams (2009) revealed that FDI inflow exhibits a negative impact on economic growth in the short-run through its unfavorable effect on home investment.

Other studies maintain neutral ground regarding the impact of FDI inflow on economic growth. Mohamed et al. (2017) submit that there is no causal effect between FDI inflow and economic growth. Similarly, Prasanna (2010) investigates the indirect impact of FDI inflow on domestic investment in India and found that the relationship between the series is uncertain.

Fedderke and Romm (2006) contend that FDI inflow is responsible in part for capital flight in the domestic economy. Belloumi (2003) investigated the relationship between FDI inflow and economic growth in Tunisia. The finding revealed that the controversial positive impact of FDI inflow is nothing rather than an empirical fallacy in the research world.

Alfaro et al. (2004) submit that the impact of FDI inflow is tied to other factors such as financial improvement, thus, the direct impact of FDI inflow is uncertain and deceptive. Similarly, studies (See: Flora and Agrawa 2014; Pandya and Sisombat 2017; Mehic et al. 2013) reject the presumed impact of FDI inflow.

The submission of Goh et al. (2017) is in line with that of Bezuidenhout (2009). These studies failed to validate the impact of FDI inflow on economic growth, confirming the work of Mah (2010) and Khobai et al. (2017). Similarly, the study of Joshua and Alola (2020) found that the FDI-led growth hypothesis is a fallacy in South Africa.

Zandile and Phiri (2019) failed to establish the FDI-led growth hypothesis aligning with the work of Goh et al. (2017) for the Asian. The above studies opine that the impact of FDI on economic growth is not real. Joshua et al. (2020) adopted the TY causal link between trade openness, GDP population, and FDI inflow in Nigeria. The findings revealed that FDI inflow is not a driver of economic growth aligning with the work of Joshua et al. (2020b).

In a related development, the potency of external loans to augment domestic saving is still contentious in the research world particularly from studies (See Moh'd and Jaradat 2019; Umaru et al. 2013; Sulaiman and Azeez 2012; Fosu 1996). One of the early studies 
on the subject (Fosu, 1996) examined the relationship between external debt and economic growth and found that external debt is a key promoter of economic growth in Sub-Saharan Africa contradicting the study of Umaru et al. (2013). Umaru et al. (2013) examine the subject matter and found that external debt is detrimental to economic growth both in the short-run and long-run. Further revelation shows that domestic loan is more beneficial compare to its foreign counterpart.

Moh'd and Jaradat (2019) investigated the relationship between external debt and economic growth in Jordan. The findings validate the negative correlation between the series and suggested relying on other sources of foreign capital such as FDI inflow. Amadou (2011) examines the effect of external capital on domestic investment in Togo. The result proves that external debt positively affects domestic investment in a significant way. Prasad et al. (2007) investigate the relationship between foreign capital and economic growth in a sample of countries consist of transitory, industrial, non-transitory, and non-industrial economies. The outcome invalidates the conventional theory that external loans will benefit the domestic economy. Jibir et al. (2018) examined the impact of external debt on economic growth in Nigeria using the dynamic ARDL approach.

The findings from the study show that external debt will cause stagnation on the path of economic growth in Nigeria. The study warned that persistent borrowing from the external sources will pose a threat to economic growth in Nigeria in both terms. Odubuasi et al. (2018) carry out a similar study in Nigeria and found a contradictory result indicating that external debt stock exerts a positive and significant impact on economic growth whereas debt servicing remained uncertain in determining the rate of economic growth.

\section{Theories Linking external capital and economic growth}

Generally, two opposing theories link FDI inflow with economic growth. First, the modernization theory asserts that FDI inflow (external capital) plays a key role in realizing the desired rate of economic growth. According to the theory, the spillover effect of FDI inflow such as human capital development, transfer of technology could assist in the transformation of an economy particularly the developing nations into modern and civilized form. The theory lent its support to the potency of FDI inflow on the economic growth of the host nation. Empirically, evidence abound in support of this claim. For instance, Joshua (2019) adopted the dynamic ARDL approach for Nigeria and found that FDI inflow is an integral part of economic growth similar to the work of Gungor and Regim (2017) for Nigeria. Gungor and Rigim (2017) found that FDI inflow plays key role in influencing the economic growth of Nigeria. Similarly, Asongu and Odhiambo (2020) investigate the relationship between FDI inflow and economic growth in sub-Saharan Africa. The result shows that FDI inflow drives economic growth accordingly as support 
by studies (See Shahbaz et al. 2019; Almfraji \& Almsafir 2014; Omr and Kahoulib 2013; Shahbaz \& Rahman 2012; Gungor \& Katircioglu 2010). In contrast, the dependency theory asserts that FDI inflow (capital inflow) is a panacea for economic retardation through its crowding-out effect on investment. According to the theory, FDI inflow promotes the course of capital flight through the repatriation and transfer of profits back to the home country of the foreign companies or investors, thereby weakening the rate of economic growth in the investment country. The theory further submits that FDI inflow is a way of exploiting the developing countries by the so-called developed economies as supported by some empirical proofs. For instance, (Abdouli and Hammami 2017) carry out relevant research for the Middle East and North Africa (MENA) countries and found that FDI inflow weakens the course of economic growth in Egypt and Lebanon respectively validating the work of Adams (2009). Joshua et al. (2020) adopted the TY causality test and found that FDI inflow does not drive the course of economic growth in South Africa aligning with the studies (See Pandya and Sisombat 2017; Goh et al. 2017; Mehic et al. 2013). In the case of India, Prasanna (2010) found that FDI inflow demonstrates uncertainty in its effect on economic growth confirming the work of Fedderke and Romm (2006), Belloumi (2003), and Khobai et al. (2017). These studies unanimously oppose the claim that FDI inflow engineered the economic growth of the host economy.

\section{Data and Methodology}

This study investigates the respective impact of external capital and domestic capital on economic growth and to compare which one among the two exerts more impact on the target variable (GDP). Time-series data were extracted from the World Bank database for econometric analysis for the period from 1981 to 2018. The sampled variables were carefully selected in line with the objective of the study. Thus, the functional model incorporates real GDP (constant 2010, US\$) as the target variable, while regressors are divided into domestic capital (domestic savings) DS, and the foreign capital whose components includes foreign direct investment (FDI) as net inflow (\% of GDP), external debt (ED) as external debt stocks, and foreign aids as net official development assistance (FA) received.

\section{Functional Model Specification}

Raza and Jawaid (2014), Prasad et al. (2007), Stoneman (1975), Chenery and Stout (1967) use foreign aids as a proxy for foreign capital. Prasad et al. (2007) particularly categories foreign capital into; FDI inflow, external debt and foreign aids which serve as the stepping stone for this study. However, this study differs from Chenery and Stout (1967) in term of the components that made up the external capital by incorporating FDI inflow and external debt to the model in addition to foreign aids to form the totality of foreign 
capital. Additionally, this study differs in term of modelling from the recent pieces of literature on Nigeria (See (Jibir et al. 2018; Odubuasi et al. 2018; Gungor and Rigim 2017) by identifying GDP as the target/dependent variable, while the explanatory variables include the component of domestic capital (domestic savings) and foreign capital (external debt, FDI inflow and foreign aids) which align with the work of Prasad et al. (2007) for panel study. The linear form of the model is started as follow:

$$
\begin{gathered}
R D G P=f(D S, F D I, E D, F A)(1) \\
\ln G D P_{t}=\beta_{0}+\beta_{1} \ln D S_{t}+\beta_{2} \ln F D I_{t}+\beta_{3} \ln E D_{t}+\beta_{5} \ln F A_{t}+\mu_{t} \text { (2) }
\end{gathered}
$$

Where In refers to Logarithmic value of the series, $\mu \_t$ denotes error term and $\beta$ i is the parameter for estimation.

\section{Stationary Test}

Traditionally and according to Gujarati (2009), aggregate macroeconomic variables often exhibits unstable characteristic that requires preliminary test using unit root test to obtain a minimum level of stationarity. This serves as the foundation targeted at avoiding spurious regression which can produce a misleading result, thus, inaccurate policy direction as supported by Joshua and Bekun (2020). The significance of the stationarity test also lies in its important role in choosing the most appropriate method of estimation. To achieve the objective, this study adopted the traditional unit root test namely ADF and PP developed by Dickey \& Fuller (1981) and Phillip \& Perron (1988), respectively.

The formula is as follow:

$$
\Delta Y_{t}=\beta_{1}+\beta_{2}+\delta Y_{t-1}+\sum_{i=1}^{\kappa} \alpha_{i} \Delta Y_{t-i}+\mu_{t} \text { (3) }
$$

Where, $\mu_{t}$ represent the Gaussians white noise that is assumed to have a mean value of zero, and possible autocorrelation represents series to be regressed on the time $t$.

\section{Cointegration Approach}

Testing for the presence of cointegration between variables of study is an important task in econometric estimation. The essence is to determine if the series converged in the future. One of the different possible approaches that could be adopted to achieve this objective is the dynamic ARDL method developed by Pesaran et al. (2001). The ARDL bound test to cointegration is preferred above the traditional method because it allows for the incorporation of a mixed order of integration resulting from the unit root tests in the same functional model. However, ARDL is not fit for a maximum order of I(2) and above. Besides, the non-stationarity of the dependent variable is required for the proper function of the model. Haven achieved a mixed order of integration from the stationarity 
test of this study, it was essential to adopt the ARDL approach. The technical formula is expressed as:

$$
\begin{gathered}
\Delta Z_{t}=\varepsilon_{0}+\varepsilon_{1} t+\mu_{1} \sigma_{t-1}+\sum_{i-1}^{n} \delta_{1} v_{i t-1}+\sum_{j-1}^{k} \phi_{j} \Delta Z_{t-j}+ \\
\sum_{i-1}^{n} \sum_{j-1}^{k} \omega_{i j} \Delta V_{i t-j}+\Upsilon D_{t}+\mu_{t}(4) \\
H_{0}: \alpha_{1}=\alpha_{2}=\cdots .=\alpha_{n+2}=0 \\
\left.H_{1}: \alpha_{1} \neq \alpha_{2} \neq \cdots+2\right) \alpha_{n+2} \neq 0
\end{gathered}
$$

The rejection of the $H_{0}$ implies a co-movement of the series in the long run and vice versa.

\section{Preliminary Analysis}

First, Figure 1 portrays the drifting nature of the macroeconomics variables as asserted by Gujarati (2009). Domestic saving indicates serious unstable movement while GDP demonstrates more stable movement along its path. Table 1 shows that GDP demonstrates a higher value of mean average, with GDP as the least. The rate of dispersion of the variables measure by comparing the standard deviation with the mean indicates that the series are extremely dispersed from their mean whereas domestic saving, FDI inflow, and external debt demonstrate negative skewness. The normal distribution of the series is validated by the Jargue-Bera test ( $p$-value $>0.05$ ). Consequently, Table 2 presents the result from the correlation matrix which indicates that domestic saving is perfectly correlated with GDP as earlier expected. This could suggest that domestic saving demonstrates a significant impact on economic growth in Nigeria and vice versa. The same outcome applies to foreign aids. The overall result indicates that only domestic saving and foreign aids demonstrate a perfect correlation with the GDP. The result of the unit root test as presented in Table 3 indicate an overall outcome of a mixed order of integration. For instance, the outcome from the ADF test indicates that only domestic savings, FDI inflow and foreign aids are stationary at level, whereas all others variables achieve stability at first difference. The result from PP unit root test validates this. Similarly, Figure 2 ( $a \& b)$ presents the results from the CUSUM and CUSUMSQ stability tests which indicate that the operational model is perfectly fitted and stable as supported by Joshua and Bekun (2020), Joshua et al. (2020) Joshua et al. (2021). The submission of these studies are that a model is stable if the blue line falls within the $95 \%$ band. Similarly, the model of this study was diagnosed and found to be properly specified, normally distributed, and homoscedastic. Table 7 present the longrun cointegration test result from the ARDL method. The outcome indicates that the series co-move together in the long-run. Thus, the disturbances in the short-run will be 
corrected so fast in the long run within $78 \%$ speed of adjustment as presented in table 5 through the ECT value of $-0.78 \%$.

DS

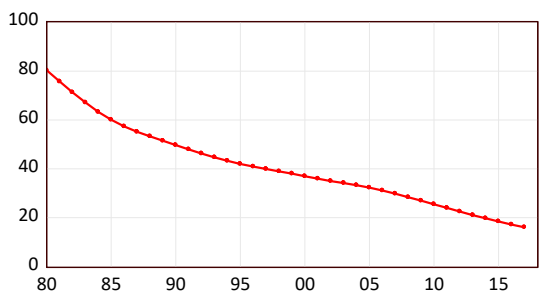

FA

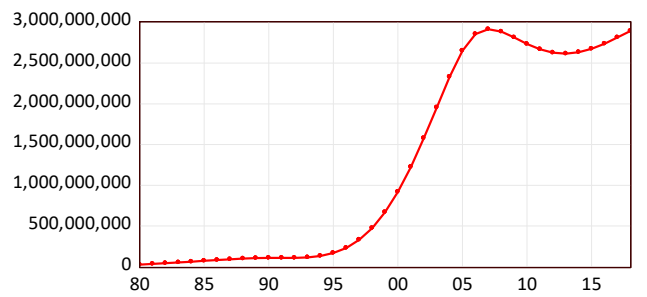

ED

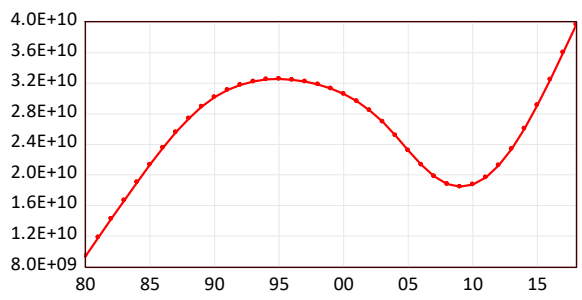

FDI

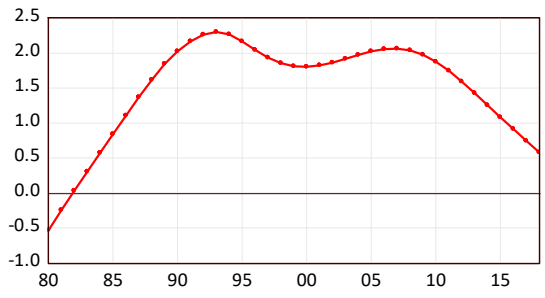

GDP

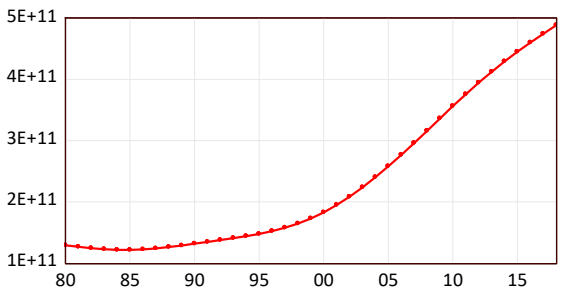

Figure 1: Trend movement of the series of interest 
Table 1: Summary Statistic

\begin{tabular}{lccccc}
\hline & GDP & DS & FDI & ED & FA \\
\hline Mean & 2.279811 & 40.91427 & 1.528186 & 2.528710 & 1.227609 \\
Median & 1.613211 & 39.63411 & 1.266578 & 2.909810 & 2.598908 \\
Maximum & 4.643411 & 87.09598 & 5.790847 & 4.058710 & 1.149810 \\
Minimum & 1.084311 & 15.71841 & -1.150856 & 8.948709 & 31709999 \\
Std. Dev. & 1.193411 & 18.25259 & 1.30879 & $8.85 \mathrm{E}+09$ & $2.15 \mathrm{E}+09$ \\
Skewness & 0.874036 & 0.732822 & 1.330622 & -0.318523 & 3.273907 \\
Kurtosis & 2.279394 & 3.089758 & 5.51324 & 1.933829 & 15.03713 \\
Jarque-Bera & $5.660467^{* *}$ & 3.413932 & $21.21445^{*}$ & 2.442367 & $297.2969^{*}$ \\
Probability & 0.058999 & 0.181415 & 0.000025 & 0.294881 & 0.000000 \\
Sum & $8.63 \mathrm{E}+12$ & 1554.742 & 58.07107 & $9.58 \mathrm{E}+11$ & $4.63 \mathrm{E}+10$ \\
Sum Sq. Dev. & $5.28 \mathrm{E}+23$ & 12326.81 & 63.37848 & $2.90 \mathrm{E}+21$ & $1.72 \mathrm{E}+20$ \\
Observations & 38 & 38 & 38 & 38 & 38 \\
\hline
\end{tabular}

Sources: Author Computation

Table 2: Correlation coefficient matrix analysis

\begin{tabular}{lccccc}
\hline Observations & GDP & DS & FDI & ED & FA \\
\hline GDP & 1.000 & & & & \\
DS & $-0.756^{* * *}$ & 1.000 & & & \\
FDI & 0.027 & -0.263 & 1.000 & & \\
ED & -0.055 & -0.249 & 0.213 & 1.000 & \\
FA & $0.499^{* * *}$ & $-0.382^{* *}$ & 0.136 & -0.259 & 1.000 \\
\hline
\end{tabular}

Table 3. Unit Root Stationarity Result

\begin{tabular}{lcccccc}
\hline Variables & ADF & P-V & I(d) & PP & P-V & I(d) \\
\hline LNGDP & -4.136 & 0.0045 & $I(1)$ & 3.972 & 0.0631 & I(0) \\
LNDS & 3.469 & 0.0008 & $I(0)$ & 4.4051 & 0.0032 & I(0) \\
LNFDI & -3.039 & 0.0004 & $I(0)$ & -3.039 & 0.0012 & I(0) \\
LNED & -4.878 & 0.0003 & $\mathrm{I}(1)$ & -4.8708 & 0.0034 & $\mathrm{I}(1)$ \\
LNFA & -3.483 & 0.0120 & $\mathrm{I}(0)$ & -5.6802 & 0.0001 & $\mathrm{I}(1)$ \\
\hline
\end{tabular}

Note: Author's Computation 

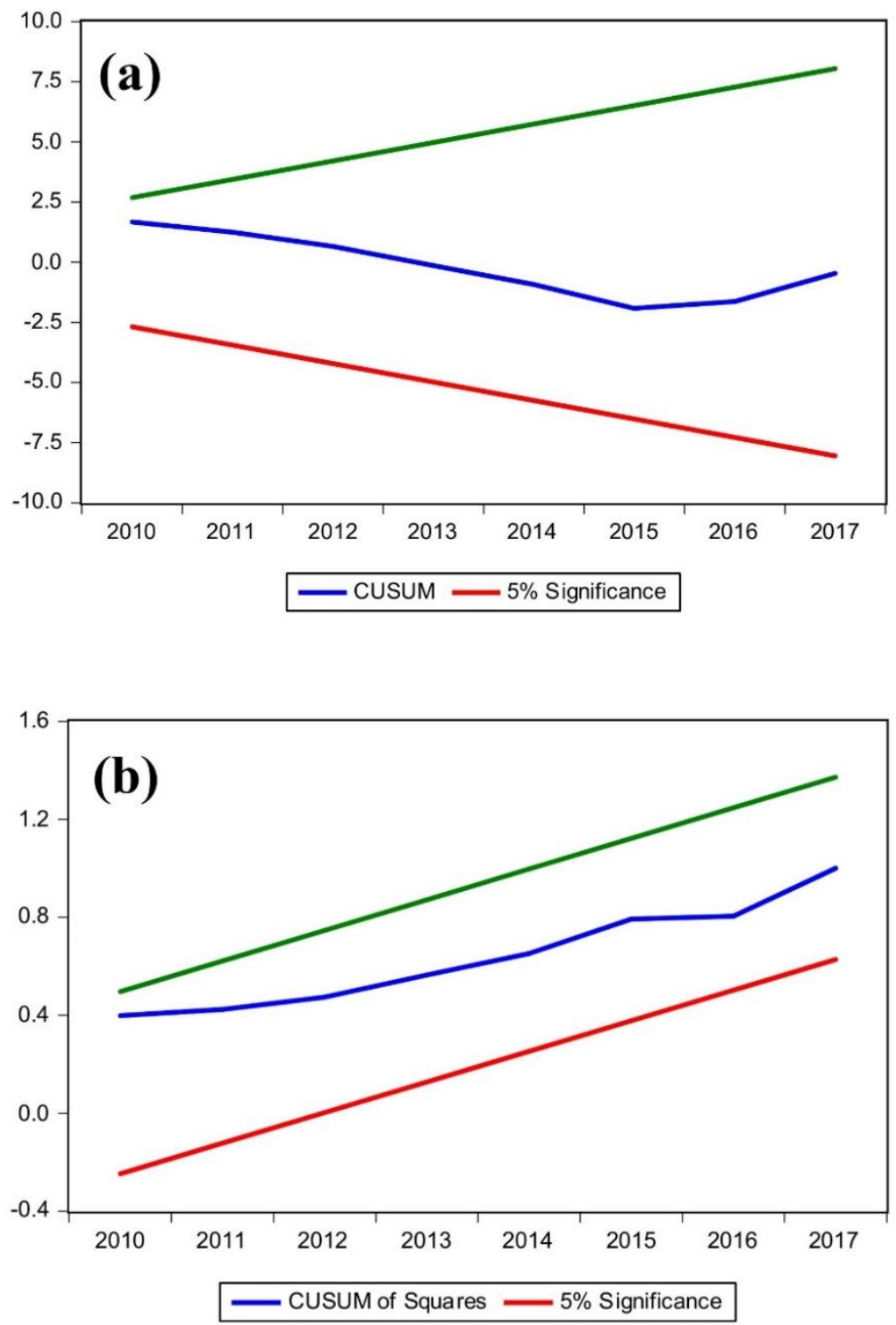

Figure 2. Stability tests (a) cumulative sum of Recursive Residuals (b) Cumulative Sum of Squares of Recursive Residuals

Table 4 presents the short-long run results from the ARDL approach. The result reveals that domestic saving exerts a positive impact on economic growth in both terms. A $1 \%$ increase in domestic saving will generate a $2.6 \%$ and $34 \%$ improvement in the rate of GDP significantly only in the long run. This suggests that domestic savings may be inconvenient 
in the short run as the production of many essential consumer products will have to be suspended to focus on capital formation or capital goods. This capital good will be used in the future to expand the production of the consumers' goods thereby promoting economic growth. In essence, in the short run, consumption has to be shifted to the accumulation of capital resources to meet investment demand which will help to generate the desired economic growth in the long run. This outcome is imperative, validating the purported key role of domestic capital in driving economic growth in Nigeria. Putting it differently, the growth equation of Nigeria's economy will demonstrate misspecification and omission of an important variable without incorporating the domestic saving component. This is instructive to the authority concern. Similarly, the result further indicates that FDI inflow exerts insignificant and negative impact on GDP in the short-run but turned out to be positive in the long run. A $1 \%$ change in the FDI inflow will cause a $0.5 \%$ opposite transformation in the rate of GDP but later turned out to be $0.9 \%$ transformation in GDP in the same direction. The implication is that FDI inflow into Nigeria may be harmful to the economy in the short run. However, in the long run, its spillover effect will erase the negative effect thereby contributing positively to the course of economic growth validating the work of Joshua et al. (2021), Gungor and Rigim (2017), Asongu and Odhiambo (2020), Shahbaz \& Rahman 2012; Shahbaz et al. 2019. One of the spillover effects could be its role in driving the orphan industries to maturity. In contrast, external debt demonstrates a negative significant impact on GDP in both terms. A $1 \%$ increase in external debt will cause a reverse effect in the rate of GDP growth by about $11.7 \%$ and $18.5 \%$ in both terms respectively. This implies that external debt component of the external capital inflow is detrimental to the course of economic growth in Nigeria as supported by the work of Moh'd and Jaradat (2019) and Jibir et al. (2018). Interestingly, the revelation from the finding shows that foreign aids is a key contributor to the path of economic growth in Nigeria. A $1 \%$ increase in foreign aids will exert a 5.1\% and $7.9 \%$ improvement in the rate of GDP growth validating the work of Chenery and Stout (1967). The study found that foreign aids promote self-sustenance and add to domestic saving. Thus, the overall result proves that despite the adverse effect of one component of foreign capital (external debt), foreign capital is partly crucial to achieving the macroeconomic goal of achieving economic growth in Nigeria which is instructive to the authority concern. 
Table 4: ARDL Result GDP=f(DS, FDI,ED,FA)

\begin{tabular}{ccccc}
\hline Variables & Coefficient & SE & t-statistic & P-Value \\
\hline Short-run & & & & \\
\hline InDS & 0.026 & 0.027 & 0.948 & 0.370 \\
InFDI & -0.005 & 0.008 & -0.606 & 0.561 \\
InED & $0.117^{* *}$ & 0.054 & 2.183 & 0.061 \\
InFA & $0.051^{* *}$ & 0.022 & 2.321 & 0.049 \\
ECT & $-0.779^{*}$ & 0.079 & -9.937 & 0.000 \\
Long run & & & & \\
InDS & $0.343^{* *}$ & 0.139 & 2.449 & 0.040 \\
InFDI & 0.009 & 0.029 & 0.320 & 0.757 \\
InED & $-0.185^{*}$ & 0.051 & -3.623 & 0.007 \\
InFA & $0.079^{* *}$ & 0.037 & 2.1493 & 0.064 \\
Diagnostic Tests & & & & \\
Tests & F-statistic & Prob. Value & & \\
NORMALITY TEST & 0.485 & 0.785 & & \\
$\chi^{2}$ SERIAL & 1.787 & 0.401 & $\mathrm{~F}(6,2)$ & \\
$\chi^{2}$ WHITE & 1.127 & 0.458 & $\mathrm{~F}(24,8)$ & \\
$\chi^{2}$ RAMSEY & 2.469 & 0.160 & $\mathrm{~F}(1,7)$ & \\
\hline
\end{tabular}

Note: The asterisks ${ }^{*}$ and ${ }^{* *}$ denote rejection of the null hypothesis at the 1 percent and 5 percent levels.

Table 5: ARDL Bounds test

\begin{tabular}{ccc}
\hline Test stat. & Value & K \\
\hline F-stat & 10.129 & 4 \\
Critical Value Bounds & & \\
significance & I(0) Bounds & I(1) Bounds \\
$10 \%$ & 3.035 & 3.997 \\
$5 \%$ & 3.578 & 4.668 \\
$1 \%$ & 5.147 & 6.617 \\
\hline
\end{tabular}

Source: Author computation

The result presented in Table 6 is drawn from the TY causality test which indicates the short-run predictive potency of the series. The revelation from the estimation indicates that except for foreign aids, all other variables are drivers of economic growth in Nigeria. This suggests that domestic savings, FDI inflow, and external debt can be used to predict the rate of economic growth in Nigeria. This is confirmed by the bidirectional link between GDP and FDI inflow, between GDP and external debt, and a unidirectional causal 
effect from domestic savings to GDP. The relationship between domestic savings and GDP from this technique confirms the outcome from the ARDL approach as reported above, while the link between FDI inflow and economic growth validates the work of Gungor and Rigim (2017) and Sunde (2017) for Nigeria and South Africa respectively, but negates the work of Joshua (2019) for Nigeria. The result further proves that FDI inflow in Nigeria could be predicted by the rate of economic growth and external debt as demonstrated by the two way drives effect between FDI inflow and GDP, as well as the one-way causal effect running from external debt to FDI inflow. The result also demonstrates that the rate of economic growth will determine the inflow of external debt and foreign aids. This is a take-home outcome for the authority and stakeholder concern.

Table 6. TY Granger Causality Results.

\begin{tabular}{lccl}
\hline Excluded & Chi-sq & df & Prob. \\
\hline Dependent variable: InGDP & & & \\
\hline InDS & $10.052^{*}$ & 1 & 0.001 \\
InFDI & $5.899^{* *}$ & 1 & 0.015 \\
InED & 8.207 & 1 & 0.004 \\
InFA & 0.162 & 1 & 0.687 \\
All & 20.559 & 4 & 0.000 \\
\hline Dependent variable: InDS & & & \\
\hline InGDP & 0.269 & 1 & 0.603 \\
InFDI & 0.031 & 1 & 0.861 \\
InED & 0.143 & 1 & 0.705 \\
InFA & 0.855 & 1 & 0.355 \\
All & 1.965 & 4 & 0.742 \\
\hline Dependent variable: InFDI & & & \\
\hline InGDP & $13.262^{*}$ & 1 & 0.000 \\
InDS & 1.147 & 1 & 0.284 \\
InED & $3.331^{* * *}$ & 1 & 0.068 \\
InFA & 1.091 & 1 & 0.296 \\
All & $16.217^{* *}$ & 4 & 0.002 \\
\hline Dependent variable: InED & & & \\
\hline InGDP & $5.771^{* *}$ & 1 & 0.016 \\
InDS & 1.715 & 1 & 0.190 \\
InFDI & 0.245 & 1 & 0.620 \\
LNFA & 0.071 & 1 & 0.790 \\
All & $11.181^{* *}$ & 4 & 0.024 \\
\hline Dependent variable: InFA & & 1 & 0.996 \\
\hline InGDP & $24.593^{*}$ & & \\
InDS & $2.28 \mathrm{E}$ & & \\
\hline & & & \\
\hline
\end{tabular}




\begin{tabular}{lccc}
\hline InFDI & 0.015 & 1 & 0.903 \\
InED & 0.094 & 1 & 0.759 \\
All & $28.287^{*}$ & 4 & 0.000 \\
\hline
\end{tabular}

Note: The asterisks $* * *$, and $* * *$ denote rejection of the null hypothesis at the 1 percent,5 percent, and 10 percent levels.

\section{Conclusion and Policy Direction}

This study mainly investigated the impact of domestic capital and its foreign counterpart on economic growth comparatively in the pre-COVID-19 pandamic in Nigeria. The result revealed that domestic savings exert a significant positive impact on economic growth. FDI inflow also exhibits a positive and insignificant impact on economic growth only in the long-run. In contrast, external debt proves to be detrimental to the course of economic growth in both terms, while foreign aids proves to be a key contributor in advancing the course of economic growth. The overall result shows that both domestic capital and foreign capital are critical factors essentially needed to achieve the desired macroeconomic goal of attaining economic growth in Nigeria with more focus on domestic resources as suggested by the dependency theory Joshua et al. (2020).

Going by the outcome above, a recommendation is made on the need for the authority concern to rely majorly on the domestic resources in resolving economic problem confronting the economy. Domestic capital formation/saving should be encouraged by the government by raising the interest rate on savings to encourage more savings by the citizens. However, if the need arises to source for more foreign capital, particularly in the case of dissaving, it must be economically motivated essentially rather than for political reasons. Frivolous borrowing plus reckless spending must be checkmate to avoid the case of unredeemable debt overhang. Among the components of external capital, external debt, in particular, must be completely discouraged. Additionally, since the result implies that Nigeria is already at the wrong side of the Laffer curve which represents a case of debt overhang, the government is advised to desist completely from external borrowing for now. This is in addition to seeking for debt cancellation or debt forgiveness terms with her foreign creditors. In line with the study of Moh'd and Jaradat (2019), this study further recommends only external capital in the form of FDI inflow and foreign aids as the best alternatives sources for foreign capital. On a concluding note, it is in the best interest of the authority concern to resort to domestic resources by borrowing in the domestic market rather than indulging in excessive foreign loans that keep retarding the course of economic growth which is capable to exert economic hardship on the citizens. This is informative for policy adjustments. 


\section{Ethical Statement Information of the Article}

$\begin{aligned} & \text { Conflict of } \\ & \text { Interest } \\ & \text { Statement }\end{aligned}$
Author
Contributions
Ethics Committee
Certificate Of
Approval

The authors declare that we has no relevant or material financial interests that relate to the research described in this paper. we thank the editor in advance and looking forward for considering my paper for possible publication in this highly esteemed journal.

Udi Joshua, conceptualized the idea, wrote the introduction, the literature review, run the estimations and interpretation, Adewale BEKE and wrote the methodology and Peter Chika UZOMBA write the conclusion and the policy implication.

In this study, there is no conflicting interest between the authors. During the process of preparing the manuscript there is no kind of financial support that has been received.

\section{References}

Abdouli, M., \& Hammami, S. (2017). The impact of FDI inflows and environmental quality on economic growth: an empirical study for the MENA countries. Journal of the Knowledge Economy, 8(1), 254-278.

Adams, S. (2009). Foreign direct investment, domestic investment, and economic growth in Sub-Saharan Africa. Journal of policy modeling, 31(6), 939-949.

Agénor, P. R., \& Montiel, P. J. (2008). Development macroeconomics. Princeton University Press.

Almfraji, M. A., \& Almsafir, M. K. (2014). Foreign direct investment and economic growth literature review from 1994 to 2012. Procedia-Social and Behavioral Sciences, 129, 206-213.

Amadou, A. (2011). The effect of foreign capital on domestic investment in Togo. International journal of economics and finance, 3(5), 223-226.

Asongu, S. A., \& Odhiambo, N. M. (2020). Foreign direct investment, information technology and economic growth dynamics in Sub-Saharan Africa. Telecommunications Policy, 44(1), 101838.

Ayanwale, A. B. (2007). FDI and economic growth: Evidence from Nigeria.

Azman-Saini, W. N. W., Law, S. H., \& Ahmad, A. H. (2010). FDI and economic growth: New evidence on the role of financial markets. Economics letters, 107(2), 211-213.

Balcilar, M., Ozdemir, Z. A., \& Shahbaz, M. (2019). On the time-varying links between oil and gold: New insights from the rolling and recursive rolling approaches. International Journal of Finance \& Economics, 24(3), 1047-1065. 
Belloumi, M. (2014). The relationship between trade, FDI and economic growth in Tunisia: An application of the autoregressive distributed lag model. Economic systems, 38(2), 269-287.

Berthélemy, J. C., \& Demurger, S. (2000). Foreign direct investment and economic growth: theory and application to China. Review of development economics, $4(2), 140-155$.

Bezuidenhout, H. (2009). A regional perspective on aid and FDI in Southern Africa. International Advances in Economic Research, 15(3), 310-321.

Borensztein, E., De Gregorio, J., \& Lee, J. W. (1998). How does foreign direct investment affect economic growth?. Journal of international Economics, 45(1), 115-135.

Chakraborty, C., \& Nunnenkamp, P. (2008). Economic reforms, FDI, and economic growth in India: a sector level analysis. World development, 36(7), 1192-1212.

Chenery, H. B. (1967). Foreign assistance and economic development. In Capital movements and economic development (pp. 268-292). Palgrave Macmillan, London.

Dao, H. T. T., \& Oanh, D. H. (2017). External debt and economic growth in Vietnam: a nonlinear relationship. China-USA Business Review, 16(1), 1-13.

Fedderke, J. W., \& Romm, A. T. (2006). Growth impact and determinants of foreign direct investment into South Africa, 1956-2003. Economic Modelling, 23(5), 738-760.

Flora, P., \& Agrawal, G. (2014). Foreign direct investment (FDI) and economic growth relationship among highest FDI recipient Asian economies: A panel data analysis. International Business Management, 8(2), 126-132.

Fosu, A. K. (1996). The impact of external debt on economic growth in Sub-Saharan Africa. Journal of Economic Development, 21(1), 93-118.

Goh, S. K., Sam, C. Y., \& McNown, R. (2017). Re-examining foreign direct investment, exports, and economic growth in asian economies using a bootstrap ARDL test for cointegration. Journal of Asian Economics, 51, 12-22.

Gujarati, D. N. (2009). Basic econometrics. Tata McGraw-Hill Education.

Gungor, H., \& Katircioglu, S. T. (2010). Financial development, FDI and real income growth in Turkey: an empirical investigation from the bounds tests and causality analysis. Actual Problems of Economics, 11(114), 215-225.

Güngör, H., Katircioglu, S., \& Mercan, M. (2014). Revisiting the nexus between financial development, FDI, and growth: New evidence from second generation econometric procedures in the Turkish context. Acta Oeconomica, 64(1), 73-89.

Hermes, N., \& Lensink, R. (2003). Foreign direct investment, financial development and economic growth. The Journal of Development Studies, 40(1), 142-163. 
Jibir, A., Abdullahi, S., Abdu, M., Buba, A., \& Ibrahim, B. (2018). External Debt-Growth Nexus in Nigeria Revisited. Asian Economic and Financial Review, 8(1), 117-130.

Joshua, U. (2019). An ARDL Approach to the Government Expenditure and Economic Growth Nexus in Nigeria. Academic Journal of Economic Studies, 5(3), 152-160.

Joshua, U. (2019). An ARDL Approach to the Government Expenditure and Economic Growth Nexus in Nigeria. Academic Journal of Economic Studies, 5(3), 152-160.

Joshua, U., \& Alola, A. A. (2020). Accounting for environmental sustainability from coalled growth in South Africa: the role of employment and FDI. Environmental Science and Pollution Research, 1-11.

Joshua, U., \& Bekun, F. V. (2020). The path to achieving environmental sustainability in South Africa: the role of coal consumption, economic expansion, pollutant emission, and total natural resources rent. Environmental Science and Pollution Research, 1-9.

Joshua, U., Bekun, F. V., \& Sarkodie, S. A. (2020). New insight into the causal linkage between economic expansion, FDI, coal consumption, pollutant emissions and urbanization in South Africa. Environmental Science and Pollution Research, 112.

Joshua, U., Bekun, F.V. \& Adedoyin, F.F. (2020) Modeling the nexus between coal consumption, FDI inflow and economic expansion: does industrialization matter in South Africa?. Environ Sci Pollut Res (2020) doi:10.1007/s11356-020-07691-x

JOSHUA, U., AMEH, A. I. I., \& ALOLA, A. A. Investment-Driven Economic Growth in Nigeria: The Role of Oil Rent. Kırklareli Üniversitesi İktisadi ve İdari Bilimler Fakültesi Dergisi, 10(1), 1-18.

Joshua, U., Babatunde, D., \& Sarkodie, S. A. (2021). Sustaining Economic Growth in SubSaharan Africa: Do FDI Inflows and External Debt Count?. Journal of Risk and Financial Management, 14(4), 146.

Joshua, U., Salami, O., \& Alola, A. (2020). Toward the path of Economic Expansion in Nigeria: The Role of Trade Globalization (No. 20/009). African Governance and Development Institute..

Khobai, H., Hamman, N., Mkhombo, T., Mhaka, S., Mavikela, N., \& Phiri, A. (2017). The FDI-growth nexus in South Africa: A re-examination using quantile regression approach.

Mah, J. S. (2010). Foreign direct investment inflows and economic growth of China. Journal of Policy Modeling, 32(1), 155-158.

Mehic, E., Silajdzic, S., \& Babic-Hodovic, V. (2013). The impact of FDI on economic growth: Some evidence from southeast Europe. Emerging Markets Finance and Trade, 49(sup1), 5-20. 
Moh'd AL-Tamimi, K. A., \& Jaradat, M. S. (2019). Impact of external debt on economic growth in Jordan for the period (2010-2017). International Journal of Economics and Finance, 11(4).

Mohamed, M. R., Singh, K. S. J., \& Liew, C. Y. (2017). Impact of foreign direct investment $\&$ domestic investment on economic growth of Malaysia. Malaysian Journal of Economic Studies, 50(1), 21-35.

Nair-Reichert, U., \& Weinhold, D. (2001). Causality tests for cross-country panels: a New look at FDI and economic growth in developing countries. Oxford bulletin of economics and statistics, 63(2), 153-171.

Odubuasi, A. C., Uzoka, P. U., \& Anichebe, A. S. (2018). External debt and Economic growth in Nigeria. Journal of Accounting and Financial Management, 4(6), 98108.

Omri and Kahoulib, (2013). Causal relationships between energy consumption, foreign direct investment and economic growth: Fresh evidence from dynamic simultaneous-equations models, 67(2014) 913-922.

Omri, A., Nguyen, D. K., \& Rault, C. (2014). Causal interactions between CO2 emissions, $\mathrm{FDI}$, and economic growth: Evidence from dynamic simultaneous-equation models. Economic Modelling, 42, 382-389.

Pandya, V., \& Sisombat, S. (2017). Impacts of Foreign Direct Investment on Economic Growth: Empirical Evidence from Australian Economy. International Journal of Economics and Finance, 9(5), 121.

Prasad, E. S., Rajan, R. G., \& Subramanian, A. (2007). Foreign capital and economic growth (No. w13619). National Bureau of Economic Research.

Prasanna, N. (2010). Direct and indirect impact of foreign direct investment (FDI) on domestic investment (DI) in India. Journal of Economics, 1(2), 77-83.

Raza, S. A., \& Jawaid, S. T. (2014). Foreign capital inflows, economic growth and stock market capitalization in Asian countries: an ARDL bound testing approach. Quality \& Quantity, 48(1), 375-385.

Shahbaz, M., \& Rahman, M. M. (2012). The dynamic of financial development, imports, foreign direct investment and economic growth: cointegration and causality analysis in Pakistan. Global Business Review, 13(2), 201-219.

Shahbaz, M., Balsalobre-Lorente, D., \& Sinha, A. (2019). Foreign direct Investment-CO2 emissions nexus in Middle East and North African countries: Importance of biomass energy consumption. Journal of cleaner production, 217, 603-614.

Shahbaz, M., Mateev, M., Abosedra, S., Nasir, M. A., \& Jiao, Z. (2019). Determinants of FDI in France: Role of Transport Infrastructure, Education, Financial Development and Energy Consumption. 
Stoneman, C. (1975). Foreign capital and economic growth. World Development, 3(1), 11-26.

Sulaiman, L. A., \& Azeez, B. A. (2012). Effect of external debt on economic growth of Nigeria. Journal of Economics and sustainable development, 3(8), 71-79.

Sunde, T. (2017). Foreign direct investment, exports and economic growth: ADRL and causality analysis for South Africa. Research in International Business and Finance, 41, 434-444.

Tang, S., Selvanathan, E. A., \& Selvanathan, S. (2008). Foreign direct investment, domestic investment and economic growth in China: A time series analysis. World Economy, 31(10), 1292-1309.

Tshepo, M. (2014). The impact of foreign direct investment on economic growth and employment in South Africa: A time series analysis. Mediterranean Journal of Social Sciences, 5(25), 18.

Umaru, A., Hamidu, A., \& Musa, S. (2013). External debt and domestic debt impact on the growth of the Nigerian economy. International Journal of Educational Research, 1(2), 70-85.

Wang, M. (2009). Manufacturing FDI and economic growth: evidence from Asian economies. Applied Economics, 41(8), 991-1002.

Yao, S. (2006). On economic growth, FDI and exports in China. Applied Economics, 38(3), 339-351.

Zandile, Z., \& Phiri, A. (2019). FDI as a contributing factor to economic growth in Burkina Faso: How true is this?. Global Economy Journal. 